Article

\title{
Shuttling between Land and Sea: Contemporary Practices among Amis Spearfishing Men as a Foundation for Local Marine-Area Management
}

\author{
Futuru C. L. Tsai \\ Department of Public and Cultural Affairs, National Taitung University, Taitung City 95092, Taiwan; \\ futuru.tsai@nttu.edu.tw; Tel.: +886-89-517-680
}

Received: 14 August 2020; Accepted: 17 September 2020; Published: 20 September 2020

\begin{abstract}
This paper explores how the Amis people on the east coast of Taiwan who practice freediving spearfishing manage the local marine area. Among the coastal Amis people, freediving spearfishing is not only a way of life but is also closely related to ritual ceremonies. Amis spearfishing men are knowledgeable of the near-shore sea and coast, and the practice of spearfishing collectively cultivates their ability to deal with both public affairs and human relations in the community. However, the Taiwanese government regards spearfishing guns as weapons and restricts them. Furthermore, the assumption that spearfishing destroys the coral ecosystem and fishery resources means that the practice is often demonized or increasingly restrained. In this paper, I argue that local marine Traditional Ecological Knowledge (TEK) among Amis spearfishing men can be the foundation for local marine conservation under the concept of community-based natural-resource management (CBNRM), involving both the local Amis community and the government, in spite of both parties still having their own issues to overcome.
\end{abstract}

Keywords: A'tolan; Amis people; freediving spearfishing; CBNRM; TEK; Taiwan

\section{Introduction}

Spearfishing with a harpoon is an ancient skill that can be traced back to more than 5000 years ago [1] (p. 6). Among the Amis people, one of Taiwan's indigenous peoples, the earliest documentation of harpoon spearfishing was in 1803; it was described by Japanese sailors who accidentally drifted to Cawi' village on the east coast of Taiwan and stayed there for four years [2] (p. 24). It is difficult to trace the earliest freediving spearfishing among Amis people, but it is possible that it started during the Japanese colonial period, when rubber and glass were introduced into Amis areas. In the Amis language, the spearfishing gun is called a pacin or cinko, which originates from the Japanese word pacinko, which means slingshot [3] (p. 4).

For the Amis people on the east coast of Taiwan, freediving spearfishing is not only a means of subsistence but is related to their society and culture. Furthermore, Amis freediving spearfishing requires complex knowledge of the nearshore sea, including the currents, fish species, marine landscapes, and related stories, which, together, can be regarded as Traditional Ecological Knowledge (TEK). The local marine TEK of the Amis freediving spearfishers regards the interactions between local Amis society and the sea, which is the foundation of the social-ecological system of indigenous resilience. In other words, the relationship between the local Amis society and the sea is, to a certain extent, interdependent, and problems on either side will also affect the other. Hence, in terms of the Amis spearfishing men's TEK about the local nearshore sea and coast, it can be a critical resource for local marine management.

However, the Taiwanese government treats spearfishing guns as weapons, and each spearfishing gun must be registered in the local police system. For this reason, Amis spearfishing men usually go 
spearfishing in a low-key manner in order to avoid law enforcement by the coast guards. However, neither the regulations nor the coast guards are sufficient to enforce the reef-fishing regulations in Taiwan. Therefore, the Fishery Agency of Council of Agriculture, Executive Yuan, introduced a preliminary notice to commence a period of public comment for drafting "Regulations of Spear Gun on Harvesting Aquatic Animals in No-take Zones" in 2017 to prohibit spearfishing based on the aim of protecting the reef ecosystem. Although the regulation allows indigenous peoples to go spearfishing according to indigenous customs in the area, the regulation is still controversial and a cause of debate. Firstly, those indigenous people living outside the indigenous jurisdictions will not be allowed to go spearfishing. Secondly, some Han Taiwanese think it is unfair that only indigenous peoples benefit from spearfishing, which could potentially cause ethnic conflict between indigenous people and the Han Taiwanese. Finally, it is not logical for the Fishery Agency to ban spearfishing based on the discourse of protecting the reef ecosystem, when it excludes the reef ecosystems from indigenous areas. In sum, the Fishery Agency does not have sufficient evidence proving that spearfishing could cause damage to the reef ecosystem. It is, therefore, argued that they do not enforce rational regulations on marine-resource conservation.

It is bound to fail with a top-down (government-controlled) strategy according to the draft regulation as above; one of the critical issues is the neglect of local TEK and the management of local natural resources, accordingly, by local communities. In terms of community-based natural-resource management (CBNRM), especially in indigenous areas, not only the TEK holders, as the local experts, but also the autonomy of indigenous groups is one of the key points for managing the natural resource. In this paper, I argue that local marine TEK among Amis spearfishing men can be the foundation for local marine conservation, following the concept of community-based natural-resource management (CBNRM) that is based on the sovereignty of the indigenous groups and transforming it into a co-management project between the local Amis community and the government.

\section{TEK as the Foundation for CBNRM}

In Taiwan, most local marine resources are governed by the government-the Fishery Agency-except for some local fishery conservation areas. To date, there is only one local-management fishery-conservation area in indigenous regions (the Fushan Fishery Conservation Area, Taitung County, Taiwan). However, the settler Han Taiwanese community manages the conservation area instead of the indigenous people, so the conservation organization has many conflicts with the local indigenous people, especially during the annual ocean ritual the local Amis people practice. In short, the Fishery Agency still practices a top-down strategy for governing marine areas. Below, I will discuss the governmentality of natural resources from the government and the context of understanding the local TEK in the face of conflicts between the government and the local communities. Furthermore, I describe how TEK can be the foundation of CBNRM, and the main associated challenges are highlighted.

\subsection{Governmentality}

Top-down governmentality is a traditional strategy for governing a nation state, focusing on the techniques and relationalities of the rules of the government $[4,5]$. Therefore, the procedure of the implementation and dissemination of policy by the bureaucratic administration is key [6]. Hence, the government usually imagines the local place based on a simple classification and quantification methodology to govern the natural resources without local knowledge [7]. In other words, the local environmental knowledge system has usually been regarded as nonrational for managing and exploiting natural resources such that the local knowledge holders are considered as non-specialists or non-technical experts in local natural-resource management systems [8].

Secondly, bureaucracy, in one way, distracts from local historical meanings and the cultural context of local natural resources and, in another sense, relocates them into a different context, which is usually defined by the urban experience of managing the natural resources [9]. Furthermore, 
the bureaucracy often relies on a certain expert system as the bridge between the state and locality to produce professional knowledge, which usually does not match local understandings of ecosystems [9].

From another perspective, governmentality cannot be regarded merely by the government but also by the local actors. Actor-network theory (ANT) implies that governance should be regarded in terms of the interaction between the government and the local actors [10]. The local actors would also represent the agency to interpret the guidance from the state and redefine it for the locality [11].

In short, the government usually neglects the local knowledge of a place, adopting a "rational" methodology to manage and exploit natural resources. Local actors do not readily accept one-way governance from the government; rather, they try to negotiate it. It is important to present the local knowledge as a "rational" system for managing local natural resources. There needs to be a discussion of what constitutes "rational", as there is a disconnect between government policy and local knowledge systems. Therefore, traditional ecological knowledge (TEK) becomes the way to negotiate with the government.

\subsection{TEK as the Agency of Natural-Resource Management}

Studies on TEK have been based on conflicts between local communities and the government, including the expert systems that the governments relied on [9]. Studies on TEK have been the focus since the 1980s due to local communities facing numerous conflicts with the rational methodology of "modern" environmental conservation, which is derived from Western scientific ideology [12].

TEK, local knowledge (LK), and indigenous environmental knowledge (IK), although somewhat different from each other, all address knowledge that was previously neglected by so-called "Western" science. These three types of knowledge focus more on the relationships of communities with the local environment and natural resources. For example, Posey argues that indigenous environmental knowledge is compatible with Western science; furthermore, it is also important to discuss the cultural rights of indigenous communities in the context of governance [13]. The first studies on indigenous environmental knowledge mostly focused on the "tradition" perspective and how traditional knowledge can be in opposition to science. In other words, earlier research on indigenous environmental knowledge also neglected its dynamics. Therefore, some scholars noticed that indigenous environmental knowledge is locally adaptive [14,15]. I define IK as a subset of TEK, which refers to a local knowledge system that is interactive with the local environment and is embedded in the context of local rituals, social interactions, social organizations, and daily practices.

In terms of the characteristics described above, we could identify TEK as an adaptive complex system of knowledge, practices, and belief, which is developed by an adaptive process in the local community with cultural practices, including the following dimensions: knowledge of local natural resources, a management system, social organization, and the context of local beliefs and worldviews [16].

\subsection{CBNRM as a Way of Self-Development}

As mentioned above, the top-down governance of environmental management has caused many conflicts in local communities, and TEK has been a focus in understanding local natural-resource management. Based on this approach, TEK can be the foundation of a management system. Therefore, community-based natural-resource management (CBNRM) can be an alternative form of governance of the local environment.

CBNRM requires the participation of local and indigenous groups with local knowledge as local (non-technical) experts from within the community. In the meantime, the principles of CBNRM can be summarized as follows. Firstly, benefit to the local population should be the priority; secondly, the TEK of the local community can be integrated into a formal management system; and thirdly, by connecting the issues on environmental destruction and social equality, non-governmental organizations (NGOs) could also bring in the social-justice issue of minority groups' treatment in the historical process as a way to get them involved [17] (pp. 1-3). 
Although CBNRM seems to solve the problem of governance failures, there are still problems that need to be tackled. First, most NGOs and the government focus on international conservation trends that they want to introduce but repress local knowledge or ignore the local political situation [18]. In other words, the government usually misunderstands the relationship between local TEK holders and external support, relying on external ecological specialists to manage the local natural resources; this means the local community or institute is ignored.

For the indigenous community, CBNRM also implies sovereignty based on the right of the indigenous peoples to govern their own environment. The new CBNRM approach emphasizes the resilience of place, state-local partnerships, subsidiarity, institutionalism, self-determination, accountability, the security of tenure/rights, and sovereignty [19]. The new trend of CBNRM stresses the local institution instead of the community; subjectivity is a weapon to force the state to be a partner in managing the environment. However, it would be romanticizing to regard the local place as a functional institution or assume the state will be effective at managing it [20]. Therefore, a local environmental management system should include local institutions, the government, related scholars, and NGOs, all of which need to cross disciplines as partners to start institutional learning and form adaptive co-management systems $[20,21]$. In sum, CBNRM could be successful with a dynamic process involving different participants and partnerships based on local places.

TEK is one of the core elements of CBNRM, and the sovereignty of the indigenous community is also key to CBNRM in indigenous regions. For the A'tolan tribe (belonging to the Amis) to manage the marine area locally, TEK and its relationships with institutions (social organizations of the community) need to be clarified. Freediving spearfishing men among the A'tolan Amis are the most knowledgeable holders of TEK of the marine area, which includes knowledge on currents, waves, underwater landscapes, fish species, coral-reef ecosystems, etc. Furthermore, the marine TEK can be classified into four categories: knowledge of the local marine area, the management system, the social organization, and the context of the local beliefs and worldview [16].

\section{TEK among Amis Freediving Spearfishing Men}

A'tolan (Dulan) is a village located in Taitung County on the southeast coast of Taiwan; it was originally inhabited by indigenous Amis people, but today, they make up only half of the total population of the village. For the Amis, the community can be understood on two different levels: one is the administrative village including all the residents in the village and its governing institutions, mostly created by the Taiwanese government, and the other is mostly based on the relationships among the local indigenous people-niyaro' (tribe) in the Amis language. The following descriptions are based on the notion of niyaro'. A'tolan is a coastal community, and the marine area is very important to local Amis culture. Gathering food from the tidal flats and ocean fishing are closely connected to Amis society and culture, and the people possess comprehensive marine knowledge. Generally speaking, the gathering activities at the intertidal zone, called "lakelaw", are mostly practiced by women and involve picking up edible seaweeds and shellfish. Sometimes, men also catch crabs or other edible marine life. As for fishing, the Amis have three traditions. They are mitilu (gill net), tafukul (throwing net), and micinko/mipacin (spearfishing) [3] (p. 2). All three kinds of fishing require substantial knowledge of the local marine life. The environmental understanding of both the intertidal zone among Amis women and the inshore open water among Amis men are fundamental to understanding the broader marine context of natural-resource management. In this paper, I focus on the freediving spearfishing men as one of the key TEK holders to start the discussion of local marine management, due to the other TEK practices needing further research in Taiwan. Since the Japanese colonial period, freediving spearfishing has been a popular and important fishing method, especially for men aged 25 to 50 .

I am going to briefly describe the local marine TEK that is practiced by A'tolan Amis spearfishing men based on the four TEK categories described above [16]. 


\subsection{Knowledge of the Local Marine Area}

Local marine knowledge is comprehensive compared to the government's, ocean scientists', and environmental NGOs' data, which is parallel to some desertification research showing that external expert knowledge is based on questionable evidence and that it has been privileged over local knowledge primarily for political, economic, and administrative reasons that do not take indigenous ecological knowledge into account [22]. For example, after a reef-check project carried out by the NGO the Taiwan Environmental Information Association from 2010 to 2013, they announced that many fish species were disappearing from the Taitung area (where A'tolan is located) or, at least, that there were no data on them [23]. However, local Amis spearfishing men have a different understanding of the situation. The reason for the different perspectives is the different methods used to recognize fish species. The NGO performs the reef check only once a year and takes only one day for it; although they use a scientific method to collect the data, their knowledge simply cannot compare with that of the local spearfishing men who dive daily as long as the conditions are good enough. Therefore, local Amis spearfishing men are familiar with the local marine area and have developed marine knowledge that the scientists or the NGOs cannot match due to discrepancies in scientific methodologies, the inadequate temporal scales that frame scientific observations, and the dismissal of the regular observations by generations of local indigenous resource users. This could be compared to Hobson's conclusion in the Canadian Arctic, where the absence of scientists from winter environments limited observational data across seasons [24].

Local marine knowledge among A'tolan Amis spearfishing men can be briefly described as follows.

\subsubsection{Fish and Other Edible Marine Life}

The names of reef fish are an important index in fishing culture among the A'tolan Amis. The fish species that are frequently speared are listed in Appendix A, Table A1.

Among the reef fish in Appendix A, Table A1, there are some features that make the local knowledge different from general biological knowledge:

1. $\mathrm{Cu}^{\prime}$ in (surgeon fish), fice'ki (gray rudderfish), sulita (octopus), and kung (pufferfish) are the favorite fish among the A'tolan Amis for consumption, especially cu'in-it has a particularly fishy smell that most Han Taiwanese people do not like, but the A'tolan Amis elders like it very much due to the gentle texture. $\mathrm{Cu}^{\prime}$ in always follow parrotfish (pihoku'ay); therefore, the parrotfish has become the index fish in the reef ecosystem, which is different from the scientific approach.

2. The fish preferred by A'tolan Amis can generally be classified into two types, based either on the morphology or habitual behaviors of the fish or on the naming system, which is totally different from the scientific way.

\subsubsection{Traditional Marine Territory as a Complex System}

Taiwan is the state governed by the Han Taiwanese settlers. The indigenous peoples of Taiwan only account for slightly more than $2 \%$ of the total population of Taiwan. In the colonial history, indigenous peoples lost most of the traditional land-tenure rights. The authority formally signed "A New Partnership Between the Indigenous Peoples and the Government of Taiwan" in 2002, signed by the president and representatives of the indigenous peoples. Since that year, the government and academia have jointly initiated survey projects for the traditional territories of indigenous peoples. Since then, the authority has gradually developed a legal framework in the traditional territories of indigenous peoples. However, it focuses merely on lands and excludes private lands from indigenous traditional territories. There is only one indigenous region of the indigenous peoples that has been recognized by the government from 2002 to 2020, and most of the rest of the traditional indigenous territories still cannot be legally recognized by the state.

Since 2000, due to many large-scale tourism-development projects led by the government or consortia on the east coast of Taiwan, there have been conflicts with the local indigenous peoples [25]. 
The A'tolan Amis did not follow the legal regulation established by the authority but proclaimed their traditional territory by their own cognition on 28 February 2017, which not only includes the land territory but also the marine area (see Figure 1 for the traditional marine area). A'tolan is the first indigenous community to proclaim the traditional marine territory in Taiwan. The traditional marine territory has been identified since 2003 and has been modified several times by the A'tolan Amis. Based on the map in Figure 1, we can see that the coastal naming system is much more complex than the governmental administration's naming system. The names on the map mostly reflect social memory and geographical or marine features (for example, the current). However, the administration's naming system is much simpler, mostly following the administration villages such as Jialulan, Fushan, Dulan, Xingchang, Xinglung, Lungchang, etc. (see Appendix A, Table A2).

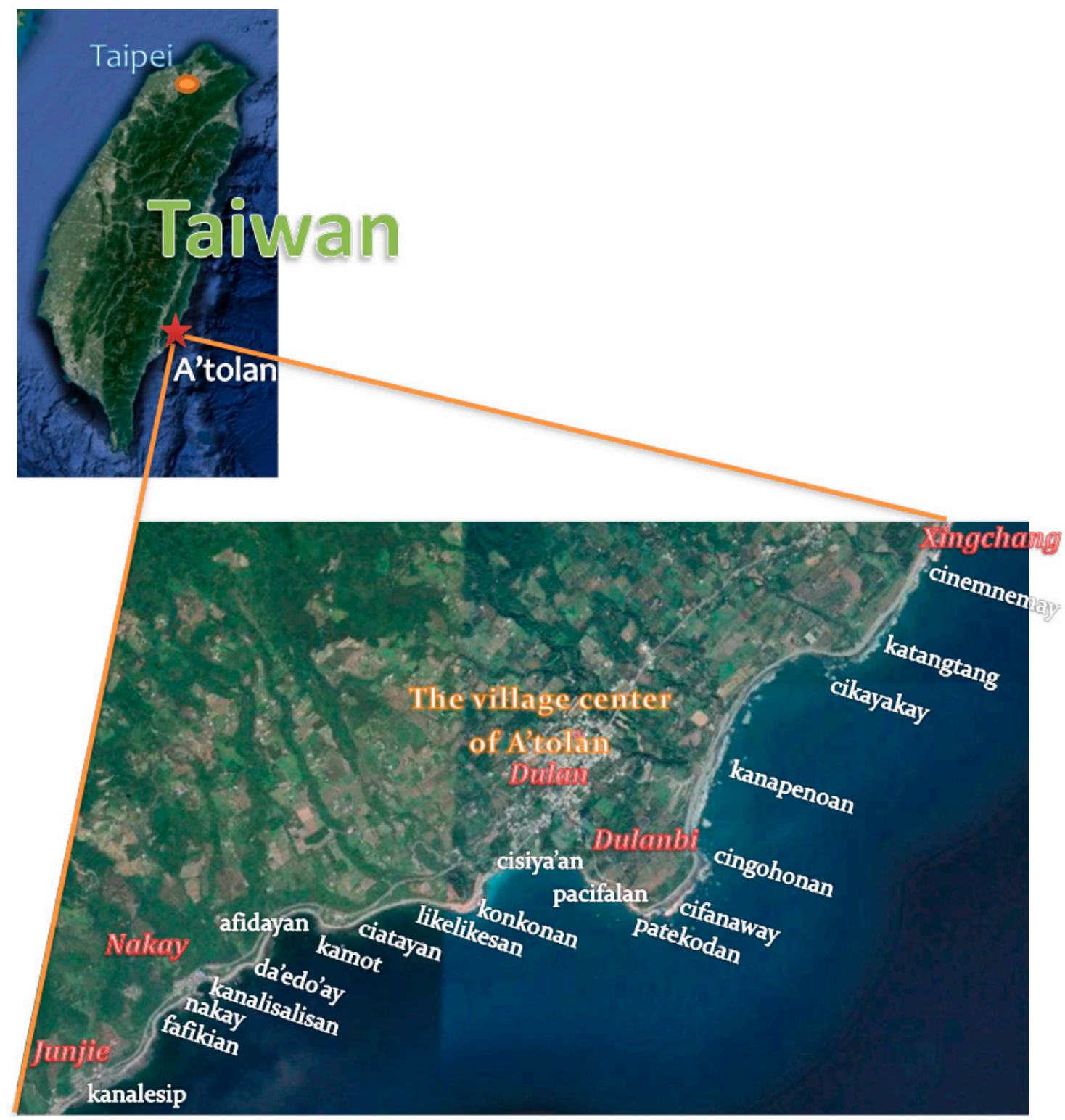

Figure 1. A'tolan Amis' traditional marine territory, italics are Chinese or Japanese names. (source: Google Maps at https://reurl.cc/b5N8V6) [26] (pp. 27-28).

1. According to the map in Figure 1, the closer to the village, the more complicated the names for coastal areas; away from the village center, the names for the marine area are fewer and simpler. 
2. Traditional names are based on different historical events, geographical features, knowledge of the inshore sea, and the nearshore terrestrial ecology [26] (pp. 26-34); once Japanese and Mandarin were introduced, some of the coastal names were changed into Chinese or Japanese. For example, Dulanbi is named in Chinese and means the nose of A'tolan, named after the geographical characteristic of protruding headland, yet A'tolan Amis have at least four names in the place of Dulanbi, which are Pacifalan (the place for locating boats), Patekodan (different currents crash here), Cifanaway (there is a hollow landscape), and Cingohonan (named after a person whose name was Ngohon who drowned here) (see Figure 2). Simply naming this protruding headland as Dulanbi in Chinese reflects the A'tolan Amis's historical memory and environmental knowledge in this area of injury and exploitation. On the contrary, reading these four traditional names of the landscapes in Dulanbi as a "political text" not only represents the knowledge of the coastal environment of the Amis people in A'tolan but is also an important foundation for decolonization [27].

3. Each coastal place could have different fish species; some places' waves are rough with strong currents, and some specific fish would come to the spot. Different fish would be away from the reef holes at certain different times during the day. Some fish would be rare in certain seasons, etc. Each spot has its own story and details about fish.

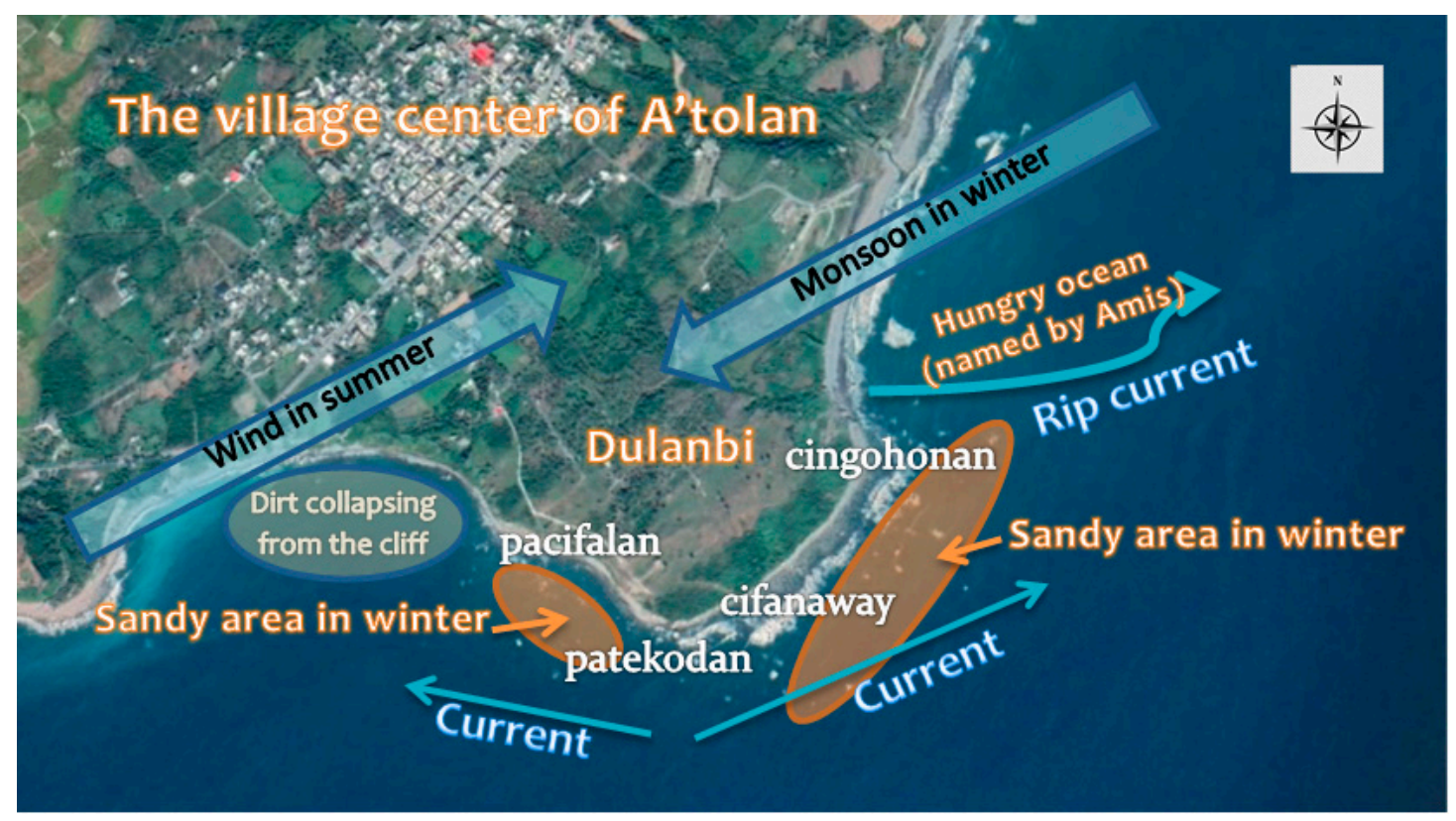

Figure 2. The currents and underwater landscapes around Dulanbi (source: based on Google Maps).

Furthermore, each spearfishing man has his favorite and least-favorite spots; the favorite one would be a "secret base", mostly because the spearfishing man had caught some big game in this area. As for the least-favorite spots, these would mostly be such because they are associated with bad memories, e.g., someone they were close to drowned there.

\subsubsection{Underwater Landscapes and Currents}

A'tolan Amis spearfishing men are very familiar with the currents and the underwater landscapes, so they can judge where and when to go freediving spearfishing and for what kind of fish. For example, the Dulanbi area is a very important fishing area for the A'tolan Amis; according to different seasons and different tides, the currents and underwater landscapes change, as Figure 2 shows.

Therefore, spearfishing men know which spots have plenty of certain fish, which season would be best to dive in, and where it is dangerous for those who are not strong divers. There are many rocks 
above the water in the marine area of A'tolan, which corresponds to stories about people who drowned nearby because they were greedy and caught too many fish.

\subsubsection{Reef Landscapes above the Water and Traditional Stories}

Most of the reef rocks appearing above the water are named after certain events, e.g., someone drowning near the rock. For example, Cionecan near Patekodan is a reef rock that appeared above the water; Onec is the name of someone who drowned near the rock. Onec was greedy and took many baskets to carry the fish, but they were too heavy to bring back to land and Onec drowned there. The name of the landscape is a part of the management system for the marine resources in A'tolan Amis society. This will be further elaborated on in the next section.

\subsubsection{The Ocean Is Understood with Reference to the Land}

The A'tolan Amis have developed a knowledge system in which they observe the relationships between the ocean and land by daily fishing or gathering. First, some fish are named after land animals due to their behavior or appearance (see Appendix A, Table A1). Secondly, senior spearfishing men can tell if underwater visibility is good based on the cloud on the mountains. If it is cloudy up in the mountains behind the village, then it might be murky underwater. Third, the A'tolan Amis always say:

Kamaro'ay a riyal, awa'ay ko fali. (No wind when the sea is sitting down.)

This old saying of the A'tolan Amis means that when there is low tide, there is no wind at all. The A'tolan Amis observe and subtly develop their knowledge of the environment. A final piece of common knowledge among the A'tolan Amis for trying to identify whether the conditions are good or not for spearfishing is the question "where is the wind coming from?". Generally speaking, when the wind is coming from the south, the waves are not good for diving because it could be very rough and fish will not leave the reef caves. However, when the wind is coming from the north, it is a good time for fishing and the waves are smoother.

\subsubsection{Water Temperature and Environmental Change}

By diving, spearfishers sense subtle changes in the ocean, especially temperature conditions. In general, the water temperature in the $A^{\prime}$ tolan marine area is 25 to $26^{\circ} \mathrm{C}$. However, at the beginning of 2016, there was a cold snap; it even snowed in the Taipei area. However, the sea temperature in that period was warmer than before. At that time, some spearfishing men were already predicting that a large typhoon would hit. In the end, there were three severe typhoons that hit Taiwan, including Typhoons Nepartak, Meranti, and Megi. Especially, Typhoon Nepartak, with record-breaking strong wind, caused a very serious disaster in the Taitung area in July 2016. At the beginning of 2017, spearfishers sensed that the sea temperature was lower but the land temperature was higher than in the previous year, although they did not use any scientific measuring tools or methods.

The TEK system of A'tolan Amis spearfishers is very complicated and full of details about the local marine area that policymakers, scientists, and environmental NGOs cannot understand without daily practice of diving in the local marine area.

\subsection{The Management System}

There are persistent governance institutions of the A'tolan Amis that influence local marine-resource management; however, the region is also facing new challenges, such as climate change, tourism development, and chemical pollution from agriculture. In terms of daily practices among A'tolan Amis spearfishing men, they involve informal institutions in which Amis governance is adapting and reshaping customary governance institutions. 


\subsubsection{Sustainable Fishing and Natural Restrictions}

As mentioned above, the marine area is affected by different seasons and wind conditions. In certain places, it would be difficult to dive due to the monsoon coming from the northeast from November to the following February. This is the windy season in A'tolan, and some locations face the wind, so the waves would be very rough to dive into. Furthermore, when the wind comes from the east, the ocean is usually murky, which prevents people from diving, especially in the periods of April to May and October to November, when the seasons are in transition in A'tolan; during that period, the visibility is not good enough to dive.

Another restriction is natural disasters. Typhoons are the issue that would limit spearfishing or other fishing activities. The most damaging typhoon to date in the Taitung area was Typhoon Morakot in 2009, which caused a lot of driftwood to float on the ocean for several months, stopping sunshine from reaching the coral reef, and then, the wood crashed into the coral. Therefore, the coral reef was destroyed by the typhoon, and the reef fish have decreased since then.

\subsubsection{Sustainable Fishing by Memory and Taboo}

As mentioned above, there are stories about how greedy men drowned in the sea, and nearby reefs are named after people who died around there. Therefore, this forms an ideology in which people cannot be too greedy in taking foods from the sea. Secondly, there is a sacred coastal place named Pacifalan that $\mathrm{A}^{\prime}$ tolan Amis people believe is the mythic place of the ancestors landing from overseas. However, the government had planned a tourism project to build up a resort on the sacred site, which is also an important fishing ground for A'tolan Amis people. The conflict between the $A^{\prime}$ tolan Amis and the authorities lasted about 10 years from 2001, and the government finally stopped the development project in 2011 [28] (pp. 97-103).

As for the taboos related to fishing among A'tolan Amis, firstly, it is not allowed to eat fish or to fish when harvesting rice, and men who have had sex the night before are not allowed to dive in the sea for fishing. Secondly, there is a dangerous inshore sea with strong rip currents that the A'tolan Amis call "the hungry ocean" limiting the number of people who are qualified to dive locally. Finally, A'tolan Amis usually do not spear sea turtles because they are the subject of a certain taboo. A'tolan Amis people believe that turtle shells are ritual objects related to the rain. The shamans of the Amis people used tortoise shells to pray for rain after a long period of drought, but if too many turtle shells were kept at home, they could cause a calamitous flood. Therefore, sea turtles have the sanctity associated with water.

\subsubsection{Sustainable Fishing by the Sense of Traditional Territory}

In the past, the A'tolan Amis would not claim ownership of the traditional marine territory in order to exclude others. However, a sense of protecting the sea has been emerging recently due to the decrease in marine resources. For example, a middle-aged man who came from the other township staying in A'tolan's traditional marine area was trying to poison lobsters; he was found by a local Amis spearfishing man, and a violent argument ensued. The Amis spearfishing man asked him to leave the territory of the A'tolan Amis. Therefore, although the A'tolan Amis think that the ocean belongs to everyone, this does not mean that others can destroy the marine ecology with impunity. In terms of the sense of traditional territory, the A'tolan Amis will start watching out and caring for marine resources. Other examples have also recently been happening. Firstly, in recent years, A'tolan Amis people have found that the parrotfish in the traditional marine area have been decreasing. In order to protect the parrotfish, the leaders in the age organization who are also experienced freediving spearfishers have banned spearing the parrotfish at night since 2017. Secondly, the new leader (kakita'an in the Amis language) of the $\mathrm{A}^{\prime}$ tolan tribe in 2020 also realized the ecological changes in the traditional marine area, and began to plan to consult the tribal members to discuss how to protect the sea. 
These customary norms and those adapting and reshaping customary governance institutions for managing local marine areas are not formally regulated among the A'tolan Amis, so there needs to be organizations in the community that will support the initiative.

\subsection{The Social Organization}

The age organization of males is an important social structure in Amis society; men are distinguished by age; with every 5 years, a new age set is established. Each age set will be given a collective name by the leader and the elderly according to the major events that occurred during their adulthood, and the females follow their husbands' age to become members of the specific age set (see Table 1) [29] (pp. 33-39). The age organization of males in A'tolan is based on the niyaro' level and is a system for taking care of community affairs, including public ceremonies and rituals. The age organization in A'tolan is still functional not only in terms of the rituals or ceremonies in the village but also the public affairs, including marine management. It is obvious that freediving spearfishing is a way to connect each individual into one integrated team (or age set) to take responsibility for the public affairs in a niyaro'. When the age set reaches the Mihiningay stage, it is time to prepare to take over the responsibility of public affairs, which happens at the Mikumoday stage. During the Mihiningay stage, the members go spearfishing together to cultivate tacit understanding. It is a training system that organizes the Amis as a team to manage public affairs, including marine management.

Table 1. The structure of the age organization of males in A'tolan (2016-2010) [29] (pp. 31-32).

\begin{tabular}{|c|c|c|c|}
\hline Categories & $\begin{array}{l}\text { General Name for } \\
\text { Age Grade }\end{array}$ & Name and Responsibility & Age Set \\
\hline \multirow{8}{*}{$\begin{array}{c}\text { Malitengay } \\
\text { People who are } \\
\text { near the ancestors }\end{array}$} & \multirow[t]{2}{*}{$\begin{array}{l}\text { Tu'as } \\
\text { The elders }\end{array}$} & $\begin{array}{l}\text { Ladihif } \\
\text { The elders who rest in the cave }\end{array}$ & $\begin{array}{l}\text { Lahetai } \\
\text { Lamindai } \\
\text { Laxinpin } \\
\text { Lakimon } \\
\text { Lakinma }\end{array}$ \\
\hline & & $\begin{array}{l}\text { Las'fi } \\
\text { The elders who rest in the gathering house }\end{array}$ & $\begin{array}{l}\text { Latiko } \\
\text { Lakocung }\end{array}$ \\
\hline & \multirow{5}{*}{$\begin{array}{c}\text { Matatapalay } \\
\text { or } \\
\text { Mi'ienengay } \\
\text { Middle-aged men }\end{array}$} & $\begin{array}{c}\text { Tukal } \\
\text { Main pillar of the house }\end{array}$ & Lajingko \\
\hline & & $\begin{array}{l}\text { Tapal } \\
\text { Learning how to be tukal }\end{array}$ & Lakensec \\
\hline & & $\begin{array}{c}\text { Culal } \\
\text { Germinating }\end{array}$ & Laencu \\
\hline & & $\begin{array}{l}\text { Romrom } \\
\text { Look out for fire }\end{array}$ & Lakancin \\
\hline & & $\begin{array}{l}\text { Mikumoday } \\
\text { The manager of the village }\end{array}$ & Lakayakay \\
\hline & Mihiningay & $\begin{array}{l}\text { Mihiningay (Miodi'ay) } \\
\text { Watching and learning }\end{array}$ & Lakanca \\
\hline \multirow{6}{*}{$\begin{array}{l}\text { Malikoday } \\
\text { Dancing people }\end{array}$} & \multirow{5}{*}{ Kapah Youth } & $\begin{array}{l}\text { Sakakaay no Kapah } \\
\text { The big brothers among youth }\end{array}$ & Lacinsi \\
\hline & & $\begin{array}{l}\text { Saka tosa no Kapah } \\
\text { The second big brother }\end{array}$ & Laliwil \\
\hline & & $\begin{array}{l}\text { Saka toro no Kapah } \\
\text { The third big brother }\end{array}$ & Ladatong \\
\hline & & Safafaay no Kapah & \multirow{2}{*}{ Lakutang } \\
\hline & & The youngest youth & \\
\hline & \multicolumn{2}{|c|}{$\begin{array}{l}\text { Pakarongay } \\
\text { The boys who serve the others }\end{array}$} & Pakarongay \\
\hline
\end{tabular}




\subsection{The Belief Context of the Sea}

The rituals related to the sea in Amis society are ocean rituals and pakelang (a ceremony in which Amis go fishing and eat fish on the coast to transfer the sacred into daily life for coastal Amis), for which each coastal Amis tribe has different words (mikesi', misace'po (which means ocean ritual in Makuta'ay village), pafafoy (which means ocean ritual in Torik village), etc.). Both ocean rituals and pakelang play a critical role in the social and cultural life of Amis. In A'tolan, mikesi' is on the last day of the annual ritual: all the males except Ladihif and Las'fi go to the coast to catch fish; women are not allowed to participate in the ritual. As for pakelang, coastal Amis get together in the coastal area to catch and cook fish at the close of a social or cultural event, e.g., a wedding, funeral, etc.

The A'tolan Amis believes that two mythical ancestors came from the ocean, so when they perform rituals and ceremonies by the coast, they call upon those two ancestors to protect the people and pray to them for fish. The two ancestors are Lepang (male) and Dongi (female). Some spearfishing men in A'tolan also call upon the ancestors' names when praying for safe diving and a rich catch of fish.

In other words, the ocean is not only a social space but also a cultural landscape for the A'tolan Amis.

\subsection{TEK in Crisis}

According to the brief introduction to local marine TEK based on the categories identified by Berkes, Colding, and Folke [15], many recent studies imply that either the indigenous TEK per se is significant $[30,31]$ or it is also effective for sustainable environmental management in collaboration with modern scientific knowledge and technology [32-34]. TEK among A'tolan Amis freediving spearfishing men could provide the basis for managing the local marine area. However, it is too romantically depicted. There are still changes happening in the environment, so TEK needs to evolve to be relevant to contemporary environmental issues. The most serious problem, for now, is the decrease in fish species in the A'tolan traditional marine area. The main reasons for this, in the understanding of the local spearfishing men, include typhoon impacts (especially Typhoon Morakot in 2009), too many commercial fishing boats using trawl and gill nets illegally, some people leaving their gill nets underwater, too many chemical insecticides being used in agriculture and flowing into the sea following rain, etc.

Typhoons and climate change are the most serious problems for the marine area of the A'tolan area from the perspective of spearfishing men. Although spearfishing men have been aware of slight changes in the water temperature for the past few years, Typhoon Nepartak, in July 2016, confirmed that the weather is changing. Typhoon Morakot, in 2009, caused very serious problems; the elders of the A'tolan Amis said that they had never experienced a typhoon that caused so much damage, especially to the coral-reef system in Taitung. In fact, in the TEK of the A'tolan Amis, typhoons are not always devastating. In their past experience, typhoons from the Pacific Ocean hit Taiwan basically every summer; sometimes, typhoons clean up the sand deposited on the bottom of inshore sea and give coral reefs a chance to regenerate. However, the typhoon phenomenon in the past few years has exceeded the understanding of the A'tolan Amis. Some typhoons are particularly violent such as Morakot in 2009 and Nepartak in 2016. From 2019 to August 2020, no typhoon even hit Taiwan. This phenomenon is beyond the past experience of A'tolan Amis, and the people can only guess it may be evidence of climate change.

Developing sustainable natural-resource management in the local marine area will need to rely on the contributions of both government agencies, ocean scientists, and environmental NGOs and Amis spear fishers-with each of these parties recognizing the strengths and limitations of the others.

\section{The Dilemma of Marine Management}

For the past three decades, studies on CBNRM have focused on the idea and practice of co-management between the government and local community. There have been many discussions and studies on forest management focusing on co-management between the indigenous community and 
the government, in the form of the Forestry Bureau in Taiwan [35-38]. However, it is ironic that Taiwan is an island state, yet the government concerns itself with fisheries more than with managing marine resources and attempts to use a top-down strategy to control marine resources. The government, which takes charge of the ocean natural resources, needs to think about how to manage them efficiently alongside the local community, and vice versa. The following section describes the dilemma of marine management from the point of view of both the government and the A'tolan.

\subsection{Inadequate Management from the State}

There was no ocean-resource management department in the Taiwanese government before 2018; the Fishery Agency (FA) took charge of this responsibility. A new governmental agency, the Ocean Conservation Administration (OCA), was established on 28 April in 2018, which is a suborganization of Ocean Affairs Council, which is also a new department in the central government of Taiwan. Compared with the Forestry Bureau (FB), not only are the FA and OCA both very small units but also their divisions of responsibilities are divided such that FA takes charge in commercial fishing and OCA takes charge in conservation of ocean. It is difficult to integrate marine-resource management when the responsible governmental agencies are separated in different departments. Furthermore, there is little understanding of the marine TEK of indigenous peoples, not only in government but also in academia. Generally speaking, coastal fishery management relies on laws and regulations made by those who do not understand local TEK, and the coast guard cannot execute the laws or regulations efficiently due to not having enough TEK training and manpower.

As for local marine-area management, current fishing law prohibits using bottom-trawl nets within three nautical miles of the shore; however, it is difficult for the coast guard to enforce this law because it has neither the suitable equipment nor enough manpower. For coral-reef resources, there are no monitoring data for setting reasonable regulations for local marine-area management.

Today, the government has no regulations managing noncommercial fishing, such as hook fishing or spearfishing. NGOs have noticed a decrease in fish in coral reefs in Taiwan and proposed a prohibition on spearfishing within 12 nautical miles of the shore on 14 March 2017. This regulation caused much debate among spearfishing men, environmental NGOs, marine biologists, and fisherman communities. The regulation was followed by a public forum on 25 June 2017 in Taipei to make the final decision on whether the state would ban spearfishing in Taiwan.

According to the draft of the regulation prohibiting spearfishing, the main purpose is to protect the coral ecology and reef-fish system in Taiwan. Ironically, indigenous peoples who spear in the indigenous area are the exception to this regulation, which implies two things: one, it is illogical to exclude the indigenous area from marine-resource management according to the draft spearfishing regulation, and two, it is unrealistic to expect that indigenous people can manage the local marine area without any external support.

The regulation regarding spearfishing has caused many arguments among the spearfishing communities; most think spearfishing is the most sustainable method. However, there is also an idea that even spearfishing needs regulating to manage the marine resources. The most critical problem, for now, is that the government does not have any reliable data with which to monitor coral-reef marine life, so they cannot issue reasonable management regulations.

In the end, the government has not enforced the law of prohibiting spearfishing at all; debates are still going on in Taiwan. There is still a lack of rational regulations for managing freediving spearfishing.

Based on CBNRM theories, getting the local community to be involved in the management system is one of the keys to successful management. However, the local community should not have to shoulder the whole responsibility for managing local natural resources, even though local TEK is more complicated than a general understanding of the local environment. 


\subsection{TEK and Local Marine Management}

TEK is not a static knowledge system but interacts with the environment to be an evolving process of knowledge. TEK on the local marine area in A'tolan can be learned from spearfishing men. However, there are still some issues that need to be surmounted. The challenges among the A'tolan Amis are as follows.

\subsubsection{Climate Disasters and Crises of Reef Fish}

As mentioned above, recent typhoon impacts have been becoming more critical and unpredictable as well as more intense. Typhoon Morakot caused major damage to the coral-reef ecosystem; fish populations have not recovered to what they were before. This is a major problem for Amis spearfishing men in A'tolan.

Furthermore, the other impact from the land is in the form of development projects, both for tourism and for agriculture. The growth of tourism brings more people, which implies that more wastewater goes into the sea without any water treatment. As for agriculture, chemical pesticides also flow into the sea. These problems cannot be managed by the local community alone; they require investigation, data collection, and a large budget to improve infrastructure.

\subsubsection{Fishing as a Way of Survival}

Most of the discourse describing freediving spearfishing regards it as a sustainable way to catch fish due to indigenous people only taking what they need at the time. Traditionally, most young Amis could spearfish on their own and did not need to buy fish. However, it cannot be denied that some of the spearfishing men make a living from spearfishing. They sell most of the fish to those whose young family members are not at home but working in the cities. In A'tolan, there is only one old spearfishing man who relies on selling fish to the villagers. This elder will sometimes spear small fish to sell. However, it seems insensitive to ask him not to spear a certain small fish because he is considered a master of spearfishing and is an elder, and according to custom, younger people need to respect their elders.

However, the younger generation is more easily managed because the age organization in A'tolan is still functional. As long as the mikumoday and the kakita'an (traditional leader) identify certain fish, sizes, seasons, conservation areas, etc., most of the younger generation will follow the rules. As for outsiders who come to the traditional marine territory, it will not be possible to enforce the regulations because the niyaro' has no authority or manpower to stop them, especially from hook fishing.

\subsubsection{Political Rights: Sovereignty}

The government does not understand the use of local TEK in managing marine areas and also does not have enough equipment or manpower to enforce the regulations, so it is not effective to manage local marine areas via top-down governance. CBNRM can be a solution to managing local natural resources, but the local community (institute) has no authority either. As Brad Coombes mentioned, an indigenous community has a sense of self-determination to defend their own environment, although internal ambivalence leads to an institutional process representing the indigeneity [19]. In other words, CBNRM in an indigenous community must be connected with the self-autonomy of the indigenous people.

Other examples of indigenous sovereignty as the key to CBNRM can be found in Hawaii. On Moloka'i, there is an indigenous community that manages its own marine area based on the local custom of consulting nature. Local indigenous communities have been forming a management system for marine areas based on some specific individuals learning local TEK, including environmental knowledge, beliefs, and the worldview to not only manage the marine area but also to teach others the TEK. This example has influenced many other Hawaiian communities and schools [39]. Therefore, there are more and more studies focusing on exploring indigenous ocean knowledge, which is utilized 
in marine management $[40,41]$. Furthermore, there are some cases stressing the relationship between marine management and Hawaii's indigenous sovereignty [42,43].

In terms of Moloka'i's case, the customary sea tenure is one of the key issues of indigenous sovereignty. The legal framework of customary sea tenure is based on local TEK, which is not only recognized by the governmental authorities but also respected by the dominant society. In other words, the practices of TEK help top establish and legitimize local sea tenure [44] (p.19). Furthermore, the recognition and reinforcement of customary sea tenure and indigenous institutions for managing local marine resources "offer the best prospect for reconnecting fractured jurisdictional domains, and for bringing about social equity, environmental protection, and self-determined regional development" [45]. Therefore, customary marine tenure systems have a better chance of success in the management of local marine resources, and governments must strengthen them to enable them to play their role in sustainable marine-resource management [46]. In sum, due to the self-determination movement in the indigenous community, there is a chance to utilize TEK in locally managing a marine area, although the community must define the unity (community) and identify the key individuals as a team (institution) to proceed with CBNRM.

In A'tolan, the age organization has been representing the niyaro' since the 1990s. It is confusing that there are three different levels taking care of the public affairs in the community, including the administration village, Community Development Association, and Cultural Association of A'tolan Amis representing niyaro'. The Cultural Association of A'tolan Amis is based on the age organization. The Cultural Association of A'tolan Amis has a plan to have the A'tolan Amis develop fishing regulations by themselves. It would take a long time to form a system for managing the local marine area without any support from the government, ocean biologists, or even NGO volunteers. Therefore, the right to autonomy of the indigenous community is important for confirming the authority of the management and obtaining support from external resources.

\section{Conclusions}

How to manage natural resources sustainably has been a long-term discussion, not only in terms of theories but also at a practical level. Traditional Ecological Knowledge has been one of the core elements in managing local natural resources, which is also one of the foundations of local social-ecological resilience. Community-based natural-resource management (CBNRM) focuses on both TEK and the local community's participation in the managing system. Recently, in indigenous areas, CBNRM has further stressed the indigeneity of self-determination and the diversity of local political interactions in the indigenous community. CBNRM needs all the parties who participate in the natural-resource management to work adaptively as part of a co-management system.

In A'tolan, Amis freediving spearfishing men have comprehensive TEK about the local marine area, which is different from the scientific perspective. A'tolan Amis have also noticed that marine resources are decreasing. However, this is barely recognized in the management plan for A'tolan marine resources, either by the government or by the community. Even if the A'tolan Amis will be in charge of protecting the local marine area, some difficulties still need to be solved. For one thing, the government needs to understand that local marine TEK is not only related to the indigenous resilience of the social-ecological system but also the key to managing local natural resources and could provide many details about the local environment such as monitoring data for scientists and NGOs. The government also needs to support the community as it comes to agreement, and sometimes, social and cultural issues are among the keys to executing natural-resource management sustainably.

On the other hand, the indigenous community needs self-determination and autonomy as it raises environmental awareness, especially about how climate change and development projects would affect local marine resources. It is necessary to cooperate with external experts in demanding sovereignty, treasuring those who have TEK and teaching it to the next generation. Scientists and NGOs also need to learn to respect local TEK and to work with local TEK knowledge-holders and the informal cultural and community institutions that support them. In this way, scientists and NGOs might become more 
effective in overcoming the misunderstanding and mistrust between the government and the local community, and become advocates for the importance of local TEK in managing and monitoring marine resources.

The co-management of forests between the government and the local indigenous community is becoming common in Taiwan at present. Ironically, though, there is a lack of discussion about co-management in marine areas. Freediving spearfishing requires knowledge of marine life and the environment. If the government wants to manage marine areas successfully, TEK from those underwater hunters can be a first step in adaptive learning for a local community or institute.

Funding: This research was funded by the Ministry of Science and Technology, Taiwan, grant numbers MOST 103-2420-H-143-002-MY3; National Academy of Marine Research, Taiwan, grant numbers NAMR-108-009.

Acknowledgments: The author is heartily grateful for the team work and inspiration provided by all research team members in the joint research project entitled "The Development of Indigenous Tribes and Environmental Changes: Exploring the Multiple Meanings of Landscape from the Perspective of Ethnic Science." Special thanks are given to all research partners in local community including my diving partners, spearfishing masters, and all the members of the age organization in A'tolan. Earlier version of this article was presented at the "2017 North American Taiwan Studies Annual Conference: RE: Taiwan as Practice, Method, and Theory", Stanford University, Stanford, CA, USA, 25-27 May 2017. The author thanks the panel participants at the conference for their valuable comments. The author thanks Mucahid M. Bayrak for assisting in the English editing of the draft of the manuscript. The author also thanks two anonymous reviewers for their constructive suggestions which improve the content of the article.

Conflicts of Interest: The author declares no conflict of interest. The funder had no role in the design of the study; in the collection, analyses, or interpretation of data; in the writing of the manuscript; or in the decision to publish the results.

\section{Appendix A}

Table A1. Fish that the A'tolan Amis spear frequently.

\begin{tabular}{lll}
\hline Po. & Amoto & Cu'in (upside-down betel nut) \\
\hline 1 & Lilid (grasshopper) & \\
\hline 3 & Fice'ki & \\
\hline
\end{tabular}


Table A1. Cont.

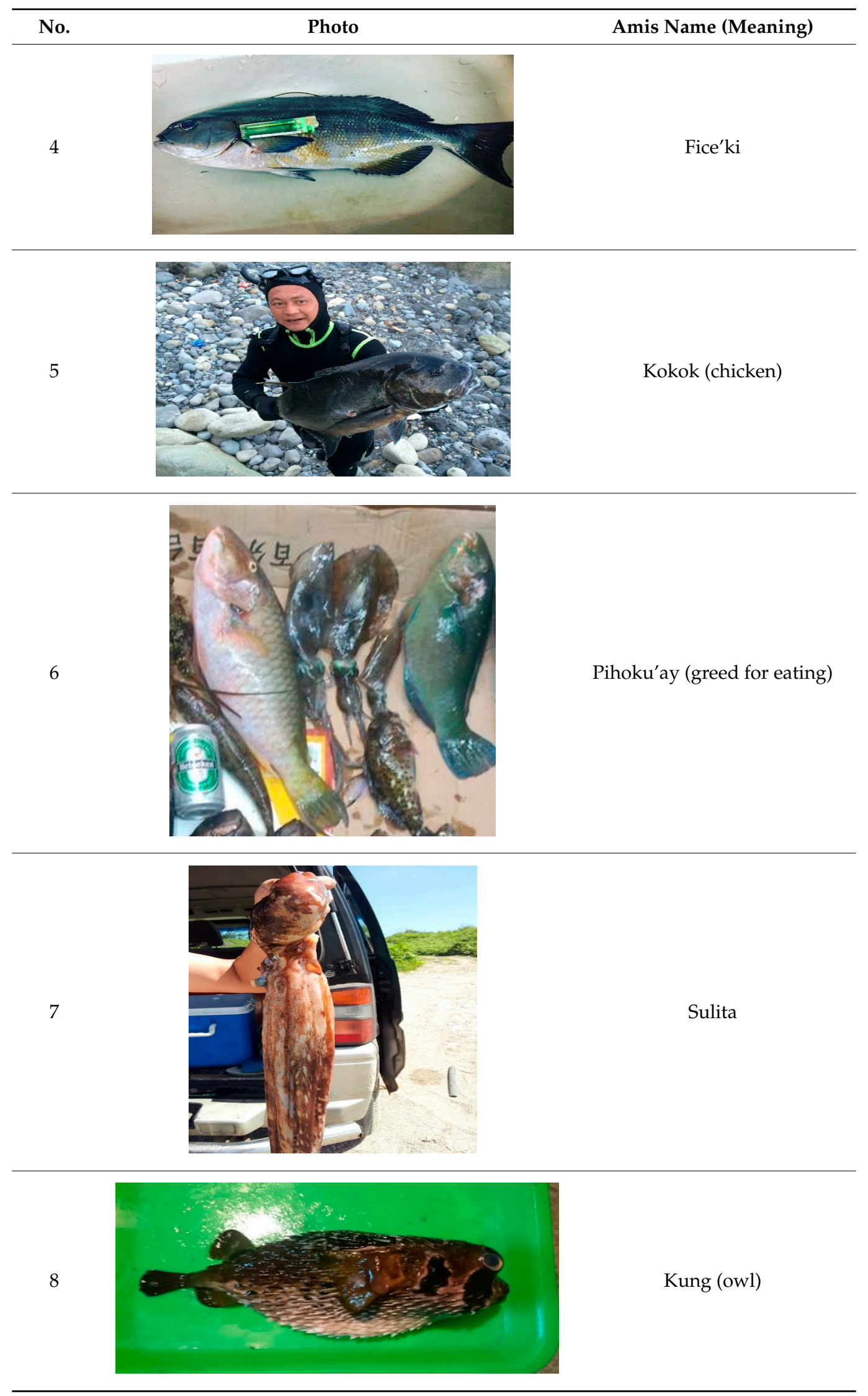


Table A1. Cont.

\begin{tabular}{lll}
\hline No. & Photo & Amis Name (Meaning) \\
\hline 9 & Kahungto'ay (pipe fish) & \\
\hline 10 & Lilateng (vegetable) & \\
\hline
\end{tabular}

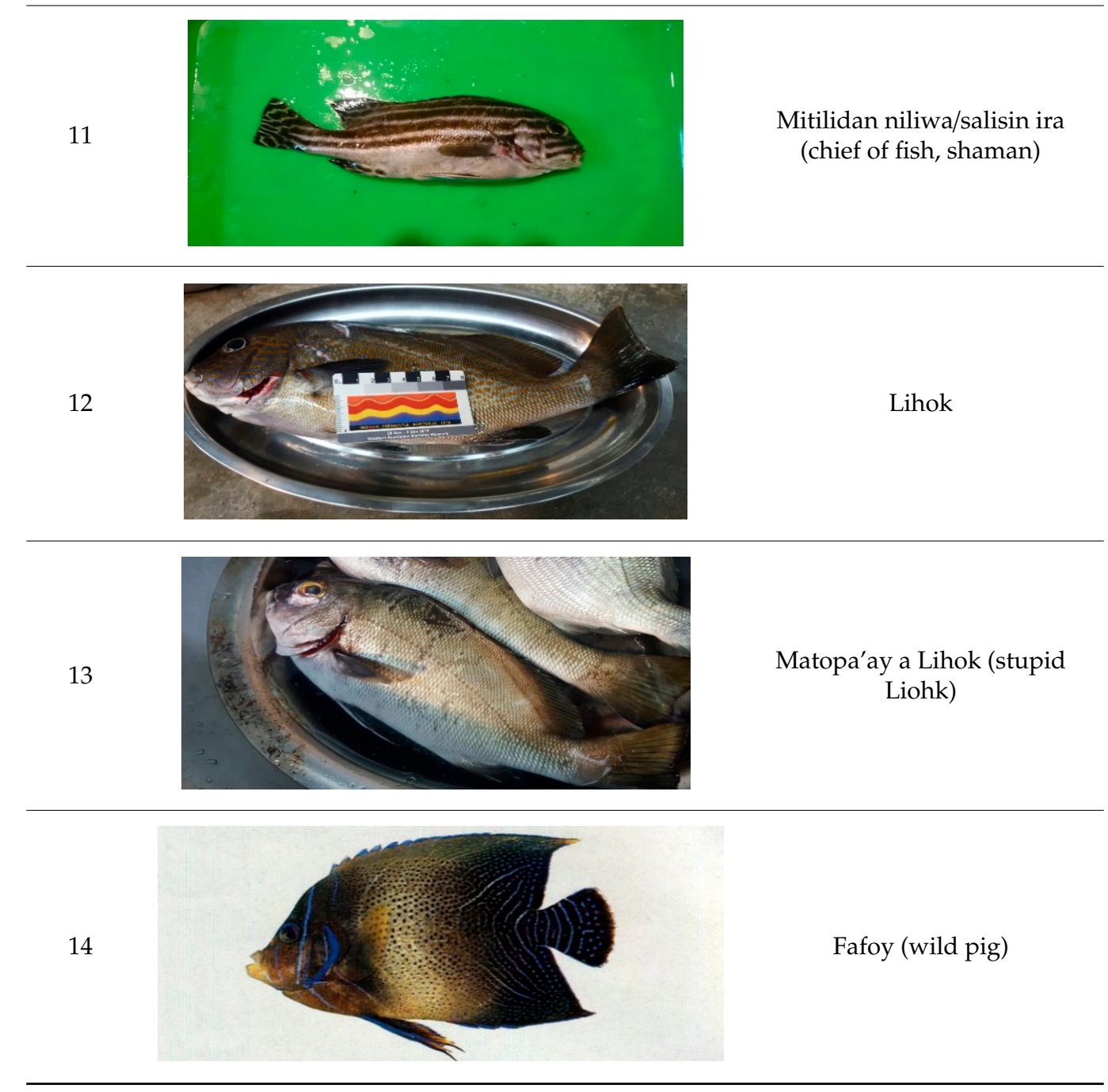


Table A1. Cont.
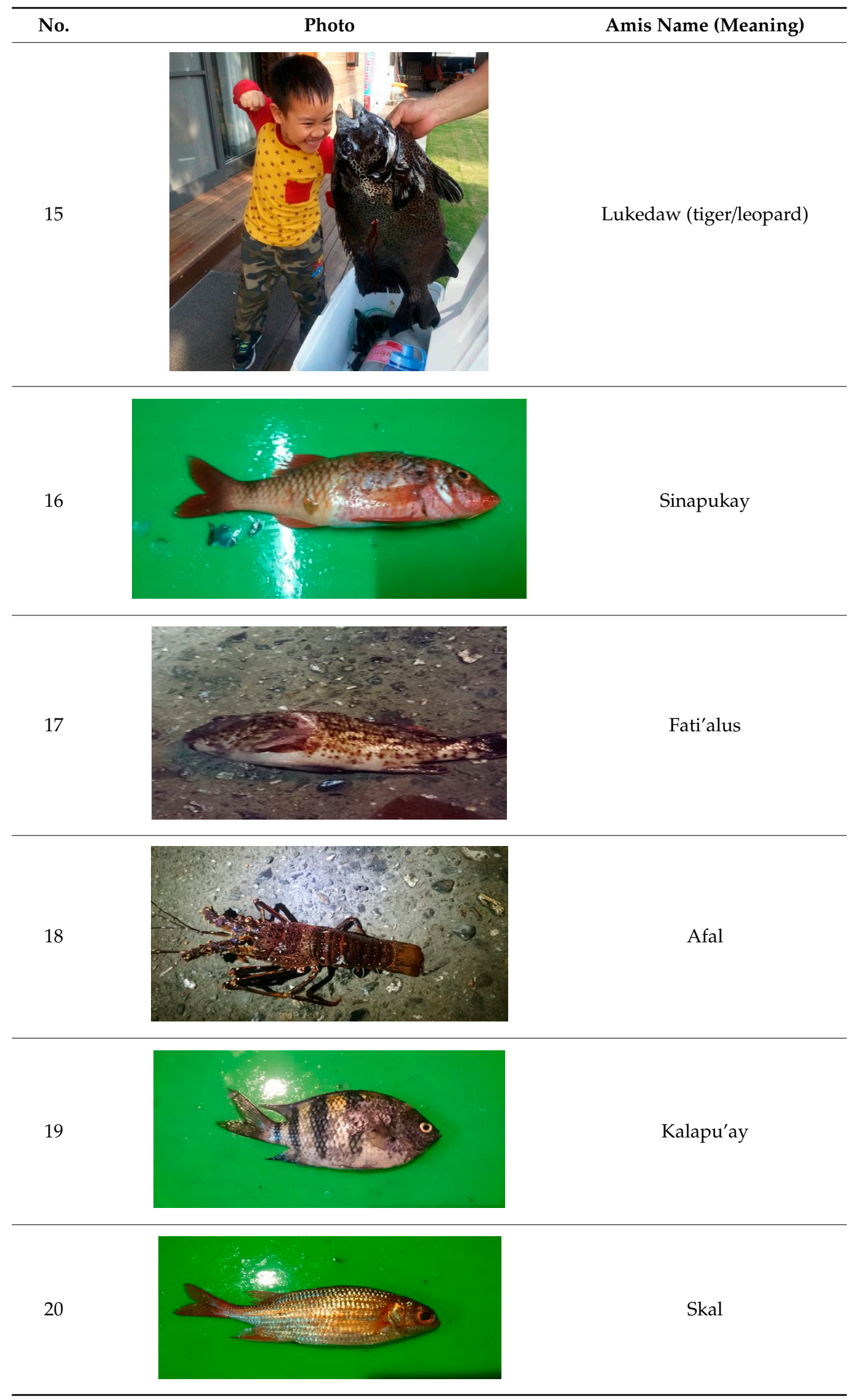
Table A2. Traditional and contemporary coastal names in the A'tolan marine territory (from north to south).

\begin{tabular}{|c|c|c|c|c|}
\hline No. & Traditional Name & Meaning & Contemporary Name & Meaning \\
\hline 1 & Kanifangal & & Longchang & Based on the administration village. \\
\hline 2 & Kilacay & & & \\
\hline 3 & Kalamuyud & & Xinglong & Based on the administration village. \\
\hline 4 & Kafafedin & & & \\
\hline 5 & Kafiki & & Yangqiao & Based on a bridge. \\
\hline 6 & Pa'anifon & & Xingchang & Based on the administration village. \\
\hline 7 & Cinemnemay & $\begin{array}{l}\text { Spring water; there is no } \\
\text { water, so this name } \\
\text { is an irony. }\end{array}$ & & \\
\hline 8 & Katangtang & The place for cooking. & Northern Kayakay & Based on the reference name in the south. \\
\hline 9 & Cikayakay & The reef as a bridge. & Kayakay & The same as the traditional name. \\
\hline 10 & Sukoan & & & \\
\hline 11 & Kanapunungan & & & \\
\hline 12 & Cingohonan & $\begin{array}{c}\text { Named after a person } \\
\text { who was drowned here. }\end{array}$ & Banshao & Banshao means military watch house. \\
\hline 13 & Cifanaway & $\begin{array}{l}\text { There is a hollow } \\
\text { landscape. }\end{array}$ & Wali & The east point of $\mathrm{A}^{\prime}$ tolan. \\
\hline 14 & Patekodan & $\begin{array}{l}\text { Different currents } \\
\text { crash here. }\end{array}$ & Wali & \\
\hline 15 & Pacifalan & $\begin{array}{l}\text { The place for } \\
\text { locating boats. }\end{array}$ & Dulanbi or Bazang & $\begin{array}{l}\text { Contemporary name for the landscape, } \\
\text { Bazang, borrowed from Hokeness, } \\
\text { the cement block. }\end{array}$ \\
\hline 16 & Cisiya'an & & & \\
\hline 17 & Kanalatip & $\begin{array}{l}\text { The waves push the land } \\
\text { to the west. }\end{array}$ & & \\
\hline 18 & Kunkunlan & $\begin{array}{l}\text { A place for } \\
\text { youth talking. }\end{array}$ & Zilaishuichang & Water station. \\
\hline 19 & Cilikesan & With many mosquitos. & Duqiao & Based on the bridge. \\
\hline 20 & Ci'ataian & $\begin{array}{c}\text { The land is shaped } \\
\text { like a liver. }\end{array}$ & Northern Jiamuzi & The southern place as the reference. \\
\hline 21 & Kamod & $\begin{array}{l}\text { Plenty of fish that could } \\
\text { be caught by hand. }\end{array}$ & Jiamuzi & Transformed from Kamod. \\
\hline 22 & Afidayan & & Jiamuzi pailion & Modern landscape. \\
\hline 23 & Da'ado'ay & $\begin{array}{l}\text { A creek runs into } \\
\text { another creek. }\end{array}$ & Qianniaoqiao & Based on the bridge. \\
\hline 24 & Kanalisalisan & $\begin{array}{l}\text { The river for } \\
\text { washing illness. }\end{array}$ & $\begin{array}{l}\text { The northern pavilion of the } \\
\text { Xinglangang }\end{array}$ & Modern landscape, the harbor. \\
\hline 25 & Nakai & & The back of Meinung & The back of Meinung's house. \\
\hline 26 & Fafikian & & $\begin{array}{l}\text { The southern pavilion of the } \\
\text { Xinglangan }\end{array}$ & Modern landscape, the harbor. \\
\hline 27 & Kanalesip & & The $151 \mathrm{k}$ tree & The landscape. \\
\hline 28 & Funto'an & $\begin{array}{l}\text { Many young men } \\
\text { wore loincloth. }\end{array}$ & Yuchang (fishing ground) & $\begin{array}{l}\text { Plenty of fish in the } \\
\text { Fushan conservation area. }\end{array}$ \\
\hline 29 & Fudafudak & The ocean was shining. & Tsitong & Based on the administration village. \\
\hline 30 & Kilam & & Changjiang (long rivier) & Based on the underwater landscape. \\
\hline 31 & Kalulu'an & & Jioukongchi & Landscape. \\
\hline 32 & Satefalan & $\begin{array}{c}\text { A place for } \\
\text { landing airplanes. }\end{array}$ & Jialulan & Based on the administration village. \\
\hline
\end{tabular}

\section{References}

1. Hamilton, S.L. Xtreme Fishing: Spearfishing; Ando Consulting Group: North Mankato, MI, USA, 2015.

2. Qin, Z.L. A Diary about Drifting to Cepo's Island in the Third Year of Xianghe; Taipei Empire University: Taipei, Taiwan, 1939.

3. Tsai, F.C.L. Micinko/Mipacin: A brief introduction to ocean culture and spearfishing among Amis. Indig. Lit. 2015, 23, 2-6. 
4. Foucault, M. Governmentality. In The Foucault Effect: Studies in Governmentality with Two Lectures by and an Interview with Michel Foucault; Burchell, G., Gordon, C., Miller, P., Eds.; Harvester Wheastsheaf: London, UK, 1991; pp. 87-104.

5. Thompson, J. Inter-institutional Relations in the Governance of England's National Parks: A Governmentality perspective. J. Rural Stud. 2005, 21, 323-334. [CrossRef]

6. Rose, N. Governing Advanced Liberal Democracies. In Foucault and Political Reason: Liberalism, Neo-Liberalism and Rationalities of Government; Barry, A., Osborne, T., Rose, N., Eds.; UCL Press: London, UK, 1996; pp. $37-64$.

7. Scott, J. Seeing Like a State: How Certain Schemes to Improve the Human Condition Have Failed; Yale University: New Haven, CT, USA, 1999.

8. Howitt, R. Local and Non-specialist Participation in Impact Assessment. In Strategic Management of Environmental and Socio-Economic Issues: A Handbook; Liu, C.-Q., Zhao, Z., Xiao, T., Guha, J., Eds.; Guizhou Science and Technology Publishing House: Guiyang, China, 2003; pp. 27-36.

9. Williams-Braun, B. Buried Epistemologies: The politics of nature in (post)-colonial British Columbia. Annal. Assoc. Am. Geogr. 1997, 87, 3-31. [CrossRef]

10. Jessop, B. The Regulation Approach, Governance and Post-fordism: Alternative perspectives on economic and political change. Econ. Soc. 1995, 24, 307-333.

11. Herbert-Cheshire, L.; Higgins, V. From Risky to Responsible: Expert knowledge and the governing of community-led rural development. J. Rural Stud. 2004, 20, 289-302. [CrossRef]

12. Lin, Y.R.; Chu, Y.Y. Something about Traditional Ecological Knowledge. Ecol. Taiwan 2004, 4. Available online: http://ecology.org.tw/publication/magazine/m-4all/11-1.htm (accessed on 20 April 2020).

13. Posey, D.A. Indigenous Management of Tropical Forest Ecosystems: The case of the Kayapo Indians of the Brazilian Amazon. Agrofor. Syst. 1986, 3, 139-158.

14. Ellen, R.; Harris, H. Introduction. In Indigenous Environmental Knowledge and Its Transformations: Critical Anthropological Perspectives; Ellen, R., Parkes, P., Bicker, A., Eds.; Harwood Academic Publishers: Singapore, 2000; pp. 1-33.

15. Bicker, A.; Sillitoe, P.; Pottier, J. (Eds.) New Approaches to Issues in Natural Resources Management, Conservation and Agriculture. In Development and Local Knowledge; Routledge: New York, NY, USA, 2004.

16. Berkes, F.; Colding, J.; Folke, C. Rediscovery of traditional ecological knowledge as adaptive management. Ecol. Appl. 2000, 10, 1251-1262. [CrossRef]

17. Brosius, J.P.; Tsing, A.L.; Zerner, C. (Eds.) Histories and Politics of Community-Based Natural Resource Management. In Communities and Conservation; Alta Mira Press: Walnut Creek, CA, USA, 2005.

18. Dressler, W.; Scher, B.B.; Schoon, M.; Brockington, D.; Hayes, T.; Kull, C.A.; Mccarthy, J.; Shrestha, K. From Hope to Crisis and Back Again? A Critical History of the Global CBNRM Narrative. Environ. Conserv. 2010, 37, 5-15.

19. Coombes, B. Defending Community? Indigeneity, Self-determination and institutional ambivalence in the Restoration of Lake Whakaki. Geoforum 2007, 38, 60-72. [CrossRef]

20. Armitage, D.R.; Berkes, F.; Doubleday, N. (Eds.) Adaptive Co-Management: Collaboration, Learning, and Multi-Level Governance; UBC Press: Vancouver, BC, Canada, 2008.

21. Berkes, F. Interdisciplinary Approaches to Coastal and Marine Resource Management. In Coasts for People; Routledge: New York, NY, USA, 2015.

22. Davis, D.K. Indigenous Knowledge and the Desertification Debate: Problematising Expert Knowledge in North Africa. Geoforum 2005, 36, 509-524. [CrossRef]

23. Chen, Z.L. The End of the Spear Gun-Civil Scientists Have Witnessed the Reef in Taiwan without Fishes; Environmental Information Center: Taipei, Taiwan, 2017. Available online: http://e-info.org.tw/node/6543 (accessed on 18 April 2020).

24. Hobson, G. Traditional Knowledge is Science. North. Perspect. 1992, $20,2$.

25. Tsai, F.C.L. Tourism Development beyond Indigenous Peoples in Eastern Taiwan. Taiwan Radic. Q. Soc. Stud. 2015, 98, 219-237.

26. Tsai, F.C.L. Amis's Traditional Marine Knowledge Research Commissioned Service; NAMR-108-009; National Academy of Marine Research: Kaohsiung, Taiwan, 2019.

27. Johnson, J.T. Place-based Learning and Knowing: Critical Pedagogies Grounded in Indigeneity. GeoJournal 2012, 77, 829-836. [CrossRef] 
28. Tsai, F.C.L. The Struggles from Identity to Practice: Contemporary Social Order and Public Affairs in the Age Organization among A'tolan Amis. Taiwan J. Indig. Stud. 2013, 6, 77-117.

29. Aggregate Corporation of Taitung County Donghe Township A'tolan Amis Cultural Association. Handbook of A'tolan Amis for the Annual Ritual in 2019; Aggregate Corporation of Taitung County Donghe Township A'tolan Amis Cultural Association: Taitung, Taiwan, 2019.

30. Nursey-Bray, M. Social Contexts and Customary Fisheries: Marine Protected Areas and Indigenous use, Australia. Environ. Manag. 2011, 47, 671-683. [CrossRef]

31. Lepofsky, D.; Caldwell, M. Indigenous Marine Resource Management on the Northwest Coast of North America. Ecol. Process. 2013, 2, 12. [CrossRef]

32. Memon, P.A.; Sheeran, B.; Ririnui, T. Strategies for Rebuilding Closer Links between Local Indigenous Communities and Their Customary Fisheries in Aotearoa/New Zealand. Local Environ. 2003, 8, $205-219$. [CrossRef]

33. Aswani, S.; Hamilton, R.J. Integrating Indigenous Ecological Knowledge and Customary Sea Tenure with Marine and Social Science for Conservation of Bumphead Parrotfish (Bolbometopon muricatum) in the Roviana Lagoon, Solomon Islands. Environ. Conserv. 2004, 31, 69-83. [CrossRef]

34. Aswani, S.; Lauer, M. Incorporating Fishermen's Local Knowledge and Behavior into geographical information Systems (giS) for Designing marine Protected areas in Oceania. Hum. Organ. 2006, 65, 81-102. [CrossRef]

35. Lin, Y.R.; Wang, H.H. Natural Resources Management: An Exploration of the Tayal Model. J. Taiwan Indig. Stud. Assoc. 2014, 4, 139-172.

36. Lu, D.J.; Wu, Y.R. An Investigation of Laws and Regulations Relating to Natural Resources Co-management. J. Taiwan Indig. Stud. Assoc. 2014, 4, 123-138.

37. Lin, Y.R. Inspiration of Wondering Around: The Tango of Resource Co-management between Forestry Bureau and Indigenous Peoples. Taiwan For. J. 2017, 43, 10-19.

38. Li, Y.R.; Lin, H.T. Facing the Historical Truth and Promoting the Co-management of the Indigenous Peoples' Forest Resources: On the road of co-management, from conflict to harmony. Taiwan For. J. 2017, 43, 1-9.

39. Poepoe, K.K.; Bartram, P.K.; Friedlander, A.M. The Use of Traditional Knowledge in the Contemporary Management of a Hawaiian Community's Marine Resources. In Fishers' Knowledge in Fisheries Science and Management; Haggan, N., Neis, B., Baird, I.G., Eds.; UNESCO: Paris, France, 2007; pp. 90-111.

40. Wiener, C.S.; Manset, G.; Lemus, J.D. Ocean Use in Hawaii as a Predictor of Marine Conservation Interests, Beliefs, and Willingness to Participate: An Exploratory Study. J. Environ. Stud. Sci. 2015, 6, 1-12. [CrossRef]

41. Friedlander, A.M.; Shackeroff, J.M.; Kittinger, J.N. Customary marine resource knowledge and use in contemporary Hawai 'i. Pac. Sci. 2013, 67, 441-460. [CrossRef]

42. Vitousek, P.; Beamer, K. Traditional Ecological Values, Knowledge, and Practices in Twenty-First Century Hawai'i. In Linking Ecology and Ethics for a Changing World; Rozzi, R., Pickett, S., Palmer, C., Armesto, J.J., Callicott, J.B., Eds.; Springer: Amsterdam, The Netherlands, 2013; pp. 63-70.

43. Nelson, M.K. Indigenous Science and Traditional Ecological Knowledge. In The World of Indigenous North America; Warrior, R., Ed.; Routledge: New York, NY, USA, 2015; pp. 188-214.

44. Cordell, J. (Ed.) A Sea of Small Boats; Cultural Survival Report 26; Cultural Survival: Cambridge, MA, USA, 1989.

45. Scott, C.H.; Mulrennan, M.E. Mare Nullius: Indigenous Rights in Saltwater Environments. Dev. Chang. 2000, 31, 681-708.

46. Asafu-Adjaye, J. Customary Marine Tenure Systems and Sustainable Fisheries Management in Papua New Guinea. Int. J. Soc. Econ. 2000, 27, 917-926. [CrossRef]

(C) 2020 by the author. Licensee MDPI, Basel, Switzerland. This article is an open access article distributed under the terms and conditions of the Creative Commons Attribution (CC BY) license (http://creativecommons.org/licenses/by/4.0/). 